\title{
PERANCANGAN SISTEM INFORMASI REKAM MEDIS PASIEN RAWAT JALAN BERBASIS WEB DI KLINIK SEHAT MARGASARI BANDUNG
}

\author{
1) Johni S Pasaribu, ${ }^{2)}$ Johnson Sihombing \\ Teknik Informatika, Politeknik Piksi Ganesha \\ J1. Jend Gatot Subroto 301 Bandung 40274 \\ email: 1)johni.pasaribu@ piksi-ganesha-online.ac.id, ${ }^{2}$ johnson.sihombing@ @iksi-ganesha-online.ac.id
}

\begin{abstract}
Abstrak
Sistem infomasi rekam medis pasien rawat jalan adalah sistem informasi yang bertujuan mengelola data pasien yang berobat hingga pasien tersebut keluar dari rumah sakit atau klinik pada periode tertentu. Sistem informasi yang dirancang sangatlah penting untuk mencegah terjadinya kesalahan prosedur dalam pelaksanaan pendaftaran dan pengelolaan data. Sistem informasi dalam klinik kesehatan ini adalah sistem informasi yang berisikan data pasien, data obat, data transaksi dan rekam medis pasien. Adapun sebelumnya kinerja sistem dalam pelayanan pasien yang berjalan pada klinik kesehatan secara umum belum optimal karena masih pada pengolahan data pasien dan data rekam medis masih menggunakan media pembukuan atau manual. Pengelolaan data pasien di Klinik Sehat Margasari masih belum efektif karena sistem yang digunakan kurang lengkap sehingga pelayanan pasien menjadi lambat dan rekam pasien sering hilang atau tidak ditemukan. Maka pelayanan pasien menjadi tidak efektif dan efisien, karena sistem manual pembukuan memperlambat pembuatan laporan atau pencarian data pasien. Sistem informasi pelayanan pasien dirancang bertujuan untuk membangun sistem informasi yang terkomputerisasi, sehingga memudahkan pihak klinik kesehatan mengolah data pasien, obat, transaksi, rekam medis, tindakan medis pasien hingga pencetakan laporan.

Hasil yang diharapkan dari penelitian ini yaitu terbangunnya sistem informasi rekam medis berbasis web untuk memudahkan Klinik Sehat Margasari dalam membantu pengolahan data pasien, obat, transaksi, rekam medis, tindakan medis pasien hingga pencetakan laporan. Rumusan masalah dari penelitian ini adalah bagaimana membangun sistem informasi rekam medis di Klinik Sehat Margasari sehingga
\end{abstract}

dapat menyajikan informasi yang akurat serta efisien. Adapun tujuan dari penelitian ini adalah menghasilkan suatu sistem informasi rekam medis pasien rawat jalan.

Kata kunci : Sistem Informasi, Rekam Medis, Pasien Rawat Jalan

\begin{abstract}
Medical record outpatient information system is a system that aims to manage the data of patients who register for treatment until the patient is discharged from the hospital or health center in a given period. The information system is important because it is designed to prevent errors in the execution of the procedure of registration and data management so that it can be done as well as possible. This information systems in health clinic is an information system that has patient data, drug data, transaction data and medical records of the patient. As before for the performance of the system in patient care in health clinic in generally not optimal because it is still in the processing of patient data and medical records are still using books or manuals. Management of patient data at the Health Clinic Margasari Bandung is still not effective because the system used is less complete so that the patient's service to be slow and patient records are often missing or was not found. Therefore care patients at health clinic become ineffective and inefficient, because manual system making slow reporting or searching data patient. Patient care information system designed aiming to establish a computerized information system, making it easier for the health clinic process patient data, drugs, transaction, medical records, medical actions to patient until print out of reports.
\end{abstract}


The expected outcome of this research is to build information system web-based to facilitate Health Clinic Margasari Bandung making it easier for the health clinic process patient data, drugs, transaction, medical records, medical actions to patient until print out of reports. Fundamental problem of this research is how to install information system for medical record patient information system at Health Clinic Margasari that make information representation accurately and efficiently. The aim of this research is to produce a information system of medical record outpatient.

Keywords : Information System, Medical Record, Outpatient

\section{Pendahuluan}

\section{I.1 Latar Belakang Masalah}

Dengan perkembangan teknologi saat ini kebutuhan terhadap informasi sangat penting sehingga informasi harus dapat diakses kapan saja dan dimana saja dan tentu telah mengalami perkembangan yang pesat. Hampir semua kegiatan yang dilakukan oleh manusia pada jaman sekarang tidak luput dari campur tangannya sebuah teknologi berbasis Online dan tentunya sudah praktis serta terkomputerisasi. Dengan adanya kepraktisan dan komputerisasi ini dapat mempermudah dalam segala pekerjaan khususnya segala pendaftaran dan pengolahan datanya membutuhkan kecepatan, ketepatan atau kevalidan data. Salah satu yang dapat dirasakan oleh dampak dari kepraktisan dan terkomputerisasi ini yaitu di bidang pelayanan kesehatan dimana memerlukan teknologi informasi yang digunakan untuk proses penyimpanan data pasien.

Berdasarkan Undang-Undang RI No. 44 tahun 2009 tentang Rumah Sakit, rumah sakit adalah institusi pelayanan kesehatan yang menyelenggarakan pelayanan kesehatan perorangan secara paripurna yang menyediakan pelayanan rawat inap, rawat jalan dan gawat darurat, serta institusi pelayanan kesehatan bagi masyarakat dengan karateristik tersendiri yang dipengaruhi oleh perkembangan ilmu pengetahuan kesehatan, kemajuan teknologi, dan kehidupan sosial ekonomi masyarakat yang harus tetap mampu meningkatkan pelayanan yang lebih bermutu dan terjangkau oleh masyarakat agar terwujud derajat kesehatan yang setinggi-tingginya.
Menurut UU no 44 tahun 2009 tentang Rumah Sakit, pasien merupakan konsultasi kesehatan yang diperlukan baik secara langsung maupun tidak langsung di rumah sakit. Salah satu bentuk pelayanan yang diberikan oleh Klinik Sehat Margasari kepada pasiennya adalah pelayanan rawat jalan. Pelayanan rawat jalan ini menangani berbagai proses dari proses registrasi rawat jalan, pemeriksaan pasien oleh dokter, resep dari dokter dan pengambilan obat di apotik Klinik Sehat Margasari, serta pembayaran biaya rawat jalan dan obat tersebut.

Selama proses yang berjalan, Klinik Sehat Margasari melakukan proses rawat jalan dengan kartu riwayat kesehatan pasien yang dsimpan oleh pihak klini yang berbentuk kertas sehingga kartu kesehatan pasien sulit untuk ditemukan ketika data riwayat pasien dibutuhkan untuk pemeriksaan rawat jalan. Oleh karena itu dibuatlah rancang bangun sistem informasi rekam medis pasien rawat jalan berbasis web di Klinik Sehat Margasari.

Adapun ruang lingkup dari sistem pelayanan pasien rawat jalan ini meliputi pengolahan data pasien, data kunjungan pasien, data riwayat kesehatan pasien, biaya pengobatan pasien dan data resep untuk pasien. Tujuan dari adanya sistem informasi pelayanan pasien rawat jalan ini adalah merancang dan membangun sebuah sistem informasi berbasis web pada Klinik Sehat Margasari. Manfaat dari sisem informasi pelayanan pasien rawat jalan adalah memudahkan resepsionis dalam pengolahan data pasien, biaya pengobatan dan mempermudah pemuatan rekapitulasi pasien rawat jalan yang dapat membantu dalam pengambilan keputusan oleh manajemen rumah sakit.

\section{I.2 Tujuan Penelitian}

Tujuan dari penelitian ini adalah untuk menghasilkan suatu Sistem Informasi Pengelolaan Data Pasien Rawat Jalan pada Klinik Sehat Margasari Bandung yang dibangun melalui tahapan-tahapan berikut: identifikasi masalah, analisis kebutuhan, perancangan dan pengembangan aplikasi, implementasi dan pengujian perangkat lunak ini sehingga dapat membangun sebuah sistem aplikasi yang menggantikan sistem manual dimana selama ini menjadi masalah serta mampu memberikan sebuah solusi sebagai bahan pertimbangan. 


\section{Tinjauan Pustaka}

\section{II.1 Pengertian Rekam Medik}

Menurut Peraturan Menteri Kesehatan Nomor: 749a/MenKes/Per/XII/1989 tentang Rekam Medik, Rekam medik adalah berkas yang berisikan catatan dan dokumen tentang identitas pasien, pemeriksaan, pengobatan, tindakan, dan pelayanan lain kepada pasien pada sarana pelayanan kesehatan. Rekam medik adalah siapa, apa, di mana dan bagaimana perawatan pasien selama di rumah sakit. Untuk melengkapi rekam medik harus dimiliki data yang cukup tertulis dalam rangkaian kegiatan guna menghasilkan suatu diagnosis, jaminan, pengobatan dan hasil akhir (SK Men PAN No. 135 tahun 2002).

\section{II.1.1. Tujuan Rekam Medik}

Menurut buku yang dikeluarkan oleh Direktorat Jendral Pelayanan Medik pada tahun 1997, Pedoman Penyelenggaraan Rekam Medik Rumah Sakit di Indonesia, tujuan utama pelayanan rekam medik di rumah sakit adalah untuk menunjang tercapainya tertib administrasi dalam rangka mengupayakan peningkatan pelayanan kesehatan di rumah sakit. Tanpa adanya dukungan suatu sistem pengelolaan rekam medik yang baik dan benar, tertib administrasi di rumah sakit tidak akan berhasil sesuai yang diharapkan. Tertib administrasi merupakan salah satu faktor yang menentukan dalam upaya pelayanan kesehatan di rumah sakit (Direktorat Jendral Pelayanan Medik, 1997).

\section{II.1.2. Kegunaan Rekam Medik}

Kegunaan rekam medik menurut Dirjen Pelayanan Medik Depkes RI No. 78 tahun 1997, dapat digunakan sebagai:

1. Sumber informasi dari pasien yang berobat ke rumah sakit untuk keperluan pengobatan dan pemeliharaan kesehatan pasien.

2. Alat komunikasi antara dokter satu dengan dokter lain, antara dokter dengan paramedik dalam usaha memberikan pelayanan pengobatan dan perawatan.

3. Bukti tertulis tentang pelayanan yang telah diberikan rumah sakit dan keperluan lain.

4. Alat untuk analisis, penelitian dan evaluasi terhadap kualitas pelayanan yang diberikan rumah sakit.

5. Alat bukti hukum yang dapat melindungi kepentingan hukum bagi pasien, dokumen tenaga kesehatan lainnya di rumah sakit.
6. Menyediakan data khusus untuk penelitian dan pendidikan (di Fakultas Kedokteran dan Keperawatan).

7. Perencanaan dan pemanfaatan sumber daya di rumah sakit.

8. Keperluan lain yang ada kaitannya dengan rekam medik.

\section{II.2 Pengelolaan Rekam Medik}

Pengelolaan rekam medik di rumah sakit biasanya dilakukan oleh Manajemen Rekam Medik, selanjutnya manajemen rekam medik telah berkembang menjadi manajemen informasi kesehatan dengan dukungan perkembangan teknologi. Rekam medik bukan lagi sekedar membuat ringkasan pasien keluar, laporan perkembangan, lembar perintah dokter, atau resume.

Semua informasi yang dihasilkan tentang seorang pasien dalam fasilitas kesehatan harus digolongkan sebagai bagian dari rekam medik. Manajemen informasi kesehatan tidak hanya mengumpulkan data pasien di fasilitas tersebut (misalnya rumah sakit), tetapi juga melindungi dan menjaga kerahasiaannya, melakukan interpretasi, dan menganalisanya untuk membuat keputusan. Pengelolaan rekam medik di suatu rumah sakit harus dilaksanakan secara benar, karena dalam rekam medik terkandung nilai-nilai vital. Nilai-nilai yang terkandung dalam dokumen rekam medik, nilai-nilai tersebut dinamakan "ALFRED VALUES" yang diartikan sebagai berikut (Direktorat Jendral Pelayanan Medik, 1997):

\section{Nilai Administrasi (Administration Value)}

Suatu berkas rekam medik mempunyai nilai administrasi, karena isinya menyangkut tindakan berdasarkan wewenang dan tanggung jawab sebagai tenaga medik dan paramedik dalam mencapai tujuan pelayanan kesehatan.

\section{Nilai Hukum (Legal Value)}

Suatu berkas rekam medik mempunyai nilai hukum, karena isinya menyangkut masalah adanya jaminan kepastian hukum atas dasar keadilan, dalam rangka usaha menegakkan hukum serta penyediaan bahan tanda bukti untuk menegakkan keadilan.

\section{Nilai Keuangan (Financial Value)}

Setiap pemeriksaan, baik pemeriksaan fisik oleh dokter, pemeriksaan penunjang medik (laboratorium, radiologi dan rehabilitasi medik), diagnostik dari 
pengobatan semuanya bernilai dengan biaya (cost) yang harus dikeluarkan demikian pula jasa pelayanan yang diberikan merupakan hak yang melekat pada dokter. Pendukung pembiayaan dan pembayaran tersebut merupakan nilai financial dalam dokumen rekam medik.

\section{Nilai Penelitian (Research Value)}

Suatu berkas rekam medik mempunyai nilai penelitian, karena isinya menyangkut data/informasi yang dapat dipergunakan sebagai bahan penelitian dan pengembangan ilmu pengetahuan di bidang kesehatan. Berbagai penelitian yang bersumber dari dokumen rekam medik dapat dilakukan dari berbagai bidang keilmuan administrasi, hukum, kedokteran, keperawatan, keuangan, gizi dan lain-lain.

\section{Nilai Pendidikan (Education Value)}

Pengertian nilai pendidikan berkaitan erat dengan penelitian oleh karena dari hasil penelitian mendidik untuk melakukan perubahan atau juga perbaikan kearah penyempurnaan pelayanan yang bermutu. Hasil penyempurnaan sistem pengisian rekam medik yang segera mendidik dokter melaksanakan kepatuhan mengisi rekam medik tepat waktu.

\section{Aspek Dokumentasi (Documentation Value)}

Dokumentasi rekam medik menjadi sumber ingatan yang senantiasa diperlukan. Pendokumentasian rekam medik haruslah baik dan tepat sehingga mudah diperoleh kembali jika diperlukan.

\section{II.2.1. Kekuatan Hukum Rekam Medik}

Kemajuan teknologi informasi dimanfaatkan oleh pihak manajemen untuk pengembangan Sistem Informasi Manajemen Rumah Sakit (SIMRS) yang terintegrasi. Tujuan utama SIMRS adalah efisiensi dan kecepatan pelayanan serta untuk pengambilan keputusan direksi, baik menyangkut keputusan terhadap pelayanan medik maupun keputusan terhadap masalah logistik, administrasi dan keuangan.

Undang-undang RI Nomor 23 Tahun 1992 tentang Kesehatan tidak mengatur secara khusus mengenai rekam medik, padahal dokumen rekam medik sebagai arsip memiliki nilai strategis (arsip vital). Aspek hukum rekam medik dapat dijelaskan sebagai berikut:
a. Kepemilikan

Dokumen rekam medik secara fisik milik institusi sarana pelayanan kesehatan, sedangkan secara isi menjadi milik pasien. Dengan demikian barang siapa yang ingin mengetahui isi dokumen rekam medik harus mendapatkan izin dan persetujuan dari pasien yang bersangkutan. Institusi/sarana pelayanan kesehatan wajib melindungi fisik dokumen rekam medik sebagai arsip.

\section{b. Penyimpanan}

Tata cara penyimpanan dokumen rekam medik harus memenuhi persyaratan pengelolaan arsip dinamis aktif maupun arsip inaktif. Rekam medik dapat dikategorikan sebagai arsip vital yang secara esensial menjamin kehidupan urusan yang masih diperlukan secara langsung, untuk penyelesaian suatu urusan bila ada kebocoran informasi ke pihak lain yang tidak berhak (sifat rahasia).

\section{II.2.2. Unit Kerja Rekam Medik (UKRM)}

Rumah sakit memerlukan informasi yang diperoleh demi pengumpulan dan pengolahan data untuk keperluan manajemen dan kesinambungan pelayanan karena rekam medik merupakan bagian dari sistem pengelolaan rumah sakit. Pada dasarnya struktur rekam medik terdiri atas dua bagian pokok yaitu pencatat atau penangkap data dan pengolah data. Ditinjau dari cara memperoleh data pasien dan mengolah data sampai memperoleh informasi yang dibutuhkan rumah sakit, unit kerja rekam medik yang berfungsi sebagai perangkat dan penghasil data rekam medik (Widiarta, 2007).

\section{II.2.3. Unit Rawat Jalan}

"Outpatient is a patient who is receiving health care service at a hospital without being hospitalized, institutionalized, and/or admitted as an inpatient". Artinya rawat jalan adalah pasien yang menerima pelayanan kesehatan di rumah sakit tanpa dirawat di rumah sakit, atau terdaftar sebagai pasien rawat inap. Pengertian tempat pendaftaran rawat jalan Rumah Sakit adalah tempat untuk setiap pasien Rumah Sakit mendaftarkan diri dalam rangka pemeriksaan diri atas status kesehatannya. Tempat pendaftaran pasien rawat jalan merupakan bagian yang bertanggung jawab terhadap data dan informasi indentitas pasien rawat jalan (Direktorat Jendral Pelayanan Medik, 1997).

Menurut jenisnya kedatangan pasien dapat dibedakan menjadi: 
1) Pasien baru adalah pasien yang baru pertama kali datang ke rumah sakit untuk keperluan berobat. Setiap pasien baru diterima di tempat penerimaan pasien dan akan diwawancarai oleh petugas guna mendapatkan data identitas yang akan diisikan pada formulir Ringkasan Riwayat Klinik. Setiap pasien baru akan memperoleh nomor pasien yang akan digunakan sebagai kartu pengenal, yang harus dibawa pada setiap kunjungan berikutnya ke rumah sakit yang sama, baik sebagai pasien berobat jalan maupun sebagai pasien rawat inap.

2) Pasien lama adalah pasien yang pernah datang sebelumnya untuk keperluan berobat. Pasien lama datang ke tempat pendaftaran pasien yang telah ditentukan. Pasien ini dapat dibedakan, yaitu:

a) Pasien yang datang dengan perjanjian.

b) Pasien yang datang tidak dengan perjanjian (atas kemauan sendiri). Baik pasien dengan perjanjian maupun pasien yang datang atas kemauan sendiri, setelah mendapat karcis, baru akan mendapat pelayanan di tempat pendaftaran pasien.

Pasien perjanjian langsung menuju poli yang dimaksud karena rekam mediknya telah disiapkan oleh petugas. Sedangkan untuk pasien yang datang atas kemauan sendiri, terus menunggu sementara rekam mediknya dimintakan oleh petugas tempat pendaftaran pasien ke bagian rekam medik. Setelah rekam mediknya dikirim ke poli, pasien akan mendapat pelayanan di poli dimaksud.

Pelayanan kesehatan rawat jalan adalah pelayanan yang diberikan kepada pasien yang tidak dirawat sebagai pasien rawat inap di rumah sakit atau institusi perawatan kesehatan yang menjadi tempat encounter. National Committee on Vital and Health Statistics telah mengadopsi definisi ini untuk pelayanan yang dilakukan di berbagai tempat perawatan jalan. Pelayanan rawat jalan (ambulatory services) adalah salah satu bentuk dari pelayanan kedokteran. Secara sederhana yang dimaksud dengan pelayanan rawat jalan adalah pelayanan kedokteran yang disediakan untuk pasien tidak dalam bentuk rawat inap (hospitalization). Dalam pengertian pelayanan rawat jalan ini termasuk tidak hanya yang diselenggarakan oleh sarana pelayanan kesehatan yang telah lazim dikenal seperti rumah sakit atau klinik, tetapi juga yang diselenggarakan di rumah pasien serta di rumah perawatan (Azwar A, 1996).
Buku Register Pendaftaran Pasien Rawat Jalan yaitu buku pencatatan yang dibuat pada Tempat Pendaftaran Pasien Rawat Jalan (TP2RJ), bagi setiap pasien rawat jalan yang mendaftar melalui Tempat Pendaftaran Pasien Rawat Jalan (TP2RJ), baik pengunjung baru maupun lama. Tujuannya adalah untuk pengunjung, cara pembayaran dari setiap pasien rawat jalan memperoleh informasi mengenai identitas pasien, jenis datang melalui Tempat Pendaftaran Pasien Rawat Jalan (TP2RJ) dan sebagai acuan langkah-langkah pelaksanaan penerimaan pasein baru dan pasien lama.

Adapun kegunaan dari Buku Register Pendaftaran Pasien Rawat Jalan yaitu (Direktorat Jendral Pelayanan Medik, 1997):

1) Untuk mengetahui jumlah kunjungan baru dan lama yang berobat jalan ke Rumah Sakit sebagai dasar pembuatan laporan.

2) Sebagai arsip TP2RJ yang harus disimpan pada unit pencatatan medik Rumah Sakit.

\section{II.2.4. Struktur Data Rekam Medis}

Struktur isi data rekam medis meliputi isi rekam medis pada pelayanan rawat jalan, gawat darurat, dan rawat inap di fasilitas pelayanan kesehatan. Sebelum membahas lebih rinci tentang item data pada rekam medis pelayanan rawat jalan terlebih dahulu disampaikan tentang data identitas pasien yang sebaiknya ada di setiap pelayanan. Menurut Bahan Ajar Pertemuan 2 Desain Formulir Rekam Medis Sekolah Vokasi Diploma Rekam Medis UGM yang ditulis oleh Savitri Citra Budi (Budi, 2013), informasi demografi diperlukan dalam mengisi informasi dasar identitas diri pasien dalam pelayanan kesehatan. Informasi ini dicatat dalam lembaran pertama rekam kesehatan rawat inap yang disebut ringkasan masuk dan keluar maupun pada lembar pertama rawat jalan yang dikenal dengan nama ringkasan riwayat klinik. Isi data demografi bersifat permanen (kekal) dan setidaknya mencakup informasi sebagai berikut: Nama lengkap (nama sendiri dan nama keluarga yaitu nama ayah/suami/marga/she); Nomor rekam kesehatan pasien dan nomor identitas lain (asuransi); Alamat lengkap pasien (nama jalan/gang, nomor rumah, wilayah, kota yang dihuni saat ini dan kode pos bila diketahui); Tanggal lahir pasien (tanggal, bulan, tahun) dan kota tempat kelahiran; Jenis kelamin (perempun atau laki-laki); Status pernikahan (sendiri, janda, duda, cerai); Nama dan alamat keluarga terdekat yang sewaktu-waktu dapat 
dihubungi; Tanggal dan waktu terdaftar di tempat penerimaan pasien rawat inap/rawat jalan/rawat gawat darurat; Nama rumah sakit (tertera pada kop formulir: nama, alamat, telepon, kota).

Beberapa pendapat tentang isi item data pada rawat jalan cukup beragam (Budi, 2013). Fasilitas pelayanan kesehatan sebagai pengguna data item tersebut dapat mengkombinasikan item data yang ada sesuai kebutuhan data di masing-masing fasilitas pelayanan kesehatan. Uniform Ambulatory Data Set (UACDS) merupakan minimum data set yang bertujuan untuk meningkatkan kemampuan untuk membandingkan data di berbagai fasilitas pelayanan rawat jalan. Di bawah ini item data menurut UACDS, yaitu: Identitas, alamat, dan jenis praktek penyedia layanan kesehatan; Tempat pelayanan kesehatan; Alasan kontak dengan layanan kesehatan mencakup keluhan \& gejala penyakit; Pelayanan diagnostik; Masalah, diagnosis, dan penilaian; Layanan terapi; Layanan pencegahan; Disposisi kepada pasien termasuk perintah dokter.

Sementara berdasarkan Permenkes 269 tahun 2008 (Budi, 2013), isi data rekam medis rawat jalan sekurang-kurangnya berisi data tentang: Identitas pasien; Tanggal dan waktu; Hasil anamnese, sekurang-kurangnya keluhan dan riwayat penyakit pasien; Hasil pemeriksaan fisik dan penunjang medis; Diagnosis; Rencana penatalaksanaan; Pengobatan dan/atau tindakan; Pelayanan lain yang telah diberikan untuk pasien; Untuk pasien kasus gigi dilengkapi dengan odontogram klinik; Persetujuan tindakan (bila diperlukan).

\section{II.3 Metode Relational Unified Process (RUP)}

Relational Unified Process (RUP) adalah pendekatan perangkat lunak yang dilakukan berulangulang (iterative), fokus pada arsitektur (architecturecentric), lebih diarahkan berdasarkan penggunaan kasus (use case driven). RUP merupakan proses rekayasa perangkat lunak dengan pendefinisian yang lebih baik (well defined) dan penstrukturan yang baik (well structured). RUP menyediakan pendefinisian yang baik untuk alur hidup proyek perangkat lunak. RUP adalah sebuah produk proses perangkat lunak yang dikembangkan oleh Rational Software yang diakuisisi oleh IBM di bulan Februari 2003.

Proses pengulangan/iteratif pada RUP secara global dapat dlihat sebagai berikut:

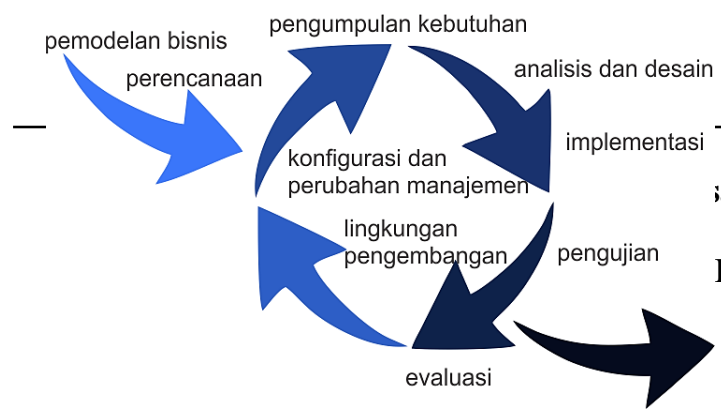

;aribu, Johnson Sihombing

Teknologi Informasi Terapan

II, No 3, 30 Agustus 2017
Gambar I. Proses iteratif RUP

Pada penelitian ini, metode RUP diterapkan mulai pada proses: pemodelan bisnis (perencanaan), pengumpulan kebutuhan, analisis dan desain, implementasi dan pengujian. Fase-fase evaluasi, lingkungan dan pengembangan, konfigurasi dan perubahan manajemen tidak diterapkan karena pembuatan perangkat lunak ini masih merupakan versi awal sehingga untuk fase-fase tersebut dilakukan pada pengembangan selanjutnya.

\section{II.4 Penelitian Terkait}

Berikut ini diberikan beberapa penelitian terkait tentang perancangan sistem informasi pasien rawat jalan.

Tabel 1. Penelitian Terkait

\begin{tabular}{|c|c|c|c|c|c|}
\hline No & Penulis & $\begin{array}{l}\text { Tahu } \\
\text { n }\end{array}$ & $\begin{array}{l}\text { Publikas } \\
\text { i }\end{array}$ & Judul & Hasil \\
\hline 1 & $\begin{array}{l}\text { Basiroh } \\
\text { dan } \\
\text { Auliya } \\
\text { Burhan } \\
\text { uddin }\end{array}$ & 2016 & $\begin{array}{l}\text { Seminar } \\
\text { Nasional } \\
\text { Teknolo } \\
\text { gi } \\
\text { Informas } \\
\text { i dan } \\
\text { Multime } \\
\text { dia } 2016 \\
\text { di } \\
\text { STMIK } \\
\text { AMIKO } \\
\text { M } \\
\text { Yogyaka } \\
\text { rta, 6-7 } \\
\text { Februari } \\
\text { 2016, } \\
\text { ISSN: } \\
\text { 2302- } \\
\text { 3805 }\end{array}$ & $\begin{array}{l}\text { Sistem } \\
\text { Informasi } \\
\text { Pengelola } \\
\text { an Data } \\
\text { Pasien } \\
\text { Rawat } \\
\text { Jalan Pada } \\
\text { Klinik } \\
\text { Akupuntur } \\
\text { dan Home } \\
\text { Care Sehat } \\
\text { MIGOEN } \\
\text { ANI }\end{array}$ & $\begin{array}{l}\text { Penelitian } \\
\text { ini } \\
\text { membuat } \\
\text { sistem } \\
\text { informasi } \\
\text { pengelolaa } \\
\text { n pasien } \\
\text { rawat jalan } \\
\text { dimana } \\
\text { memudahk } \\
\text { an petugas } \\
\text { dalam } \\
\text { menangani } \\
\text { dan } \\
\text { mengelola } \\
\text { data pasien } \\
\text { rawat } \\
\text { jalan. } \\
\text { Petugas } \\
\text { tidak perlu } \\
\text { lagi } \\
\text { menghitun } \\
\text { g secara } \\
\text { manual } \\
\text { biaya- } \\
\text { biaya yang } \\
\text { harus } \\
\text { dibayar } \\
\text { pasien } \\
\text { terkait } \\
\text { dengan } \\
\text { pengobata } \\
\text { n yang } \\
\text { dilakukann } \\
\text { ya. } \\
\text { Laporan- } \\
\text { laporan } \\
\text { juga bisa } \\
\text { langsung }\end{array}$ \\
\hline
\end{tabular}




\begin{tabular}{|c|c|c|c|c|c|}
\hline & & & & & $\begin{array}{l}\text { dicetak } \\
\text { dengan } \\
\text { mengguna } \\
\text { kan } \\
\text { printer. }\end{array}$ \\
\hline \multicolumn{6}{|c|}{$\begin{array}{l}\text { Kesimpulan: Menghasilkan sistem informasi yang dapat } \\
\text { mempermudah dalam mengelola data dokter, pasien, obat, transaksi } \\
\text { dan mencetak kartu pasien yang memudahkan administrasi } \\
\text { pendaftaran pasien saat kembali berkunjung dengan menggunakan } \\
\text { sistem pada komputer. Akan tetapi aplikasi ini belum dibuat dengan } \\
\text { berbasis web (masih bersifat off-line), sehingga user tidak bisa } \\
\text { melihat informasi secara online. Kekurangan lainnya adalah masih } \\
\text { bersifat single user, sehingga perlu dikembangkan ke dalam } \\
\text { aplikasi berbasis multi user. }\end{array}$} \\
\hline 2 & $\begin{array}{l}\text { Moham } \\
\text { ad } \\
\text { Topan, } \\
\text { Hans F. } \\
\text { Wowor } \\
\text { dan } \\
\text { Xaveri } \\
\text { us B. } \\
\text { N. } \\
\text { Najoan }\end{array}$ & 2015 & $\begin{array}{l}\text { e-journal } \\
\text { Teknik } \\
\text { Informati } \\
\text { ka, } \\
\text { volume } \\
6 \text {, No. } 1 \\
(2015) \text {, } \\
\text { ISSN : } \\
2301- \\
8364\end{array}$ & $\begin{array}{l}\text { Perancang } \\
\text { an Sistem } \\
\text { Informasi } \\
\text { Manajeme } \\
\text { n Rumah } \\
\text { Sakitakit } \\
\text { Berbasis } \\
\text { Web Studi } \\
\text { Kasus: } \\
\text { Rumah } \\
\text { Sakit TNI } \\
\text { AU } \\
\text { LANUD } \\
\text { Sam } \\
\text { Ratulangi }\end{array}$ & $\begin{array}{l}\text { Sistem } \\
\text { Informasi } \\
\text { Manajeme } \\
\text { n Rumah } \\
\text { Sakit } \\
\text { berbasis } \\
\text { web yang } \\
\text { telah } \\
\text { dihasilkan } \\
\text { pada } \\
\text { perancanga } \\
\text { n ini dapat } \\
\text { digunakan } \\
\text { untuk } \\
\text { mengelola } \\
\text { data pasien } \\
\text { rawat } \\
\text { jalan, } \\
\text { rawat inap, } \\
\text { pelayanan } \\
\text { apotik dan } \\
\text { pelayanan } \\
\text { kasir. } \\
\text { Adapun } \\
\text { setiap } \\
\text { bagian } \\
\text { pelayanan } \\
\text { dapat } \\
\text { merekap } \\
\text { seluruh } \\
\text { data pasien } \\
\text { maupun } \\
\text { data } \\
\text { keuangan } \\
\text { untuk } \\
\text { bagian } \\
\text { kasir dan } \\
\text { apotik. }\end{array}$ \\
\hline \multicolumn{6}{|c|}{$\begin{array}{l}\text { Kesimpulan: Penelitian ini membuat sistem informasi manajemen } \\
\text { rumah sakit berbasis web yang dapat mengelola data pasien untuk } \\
\text { pelayanan rawat jalan, rawat inap, apotik dan kasir menggunakan } \\
\text { metodologi waterfall. Namun akan lebih baik apabila ditambahkan } \\
\text { fitur untuk manajemen penunjang rumah sakit seperti bagian bagian } \\
\text { laboratorium, radiologi serta pendataan dokter, perawat dan } \\
\text { pegawai rumah sakit. }\end{array}$} \\
\hline
\end{tabular}

\begin{tabular}{|c|c|c|c|c|c|}
\hline 3 & $\begin{array}{l}\text { Wahyu } \\
\text { K.Dew } \\
\text { anto, } \\
\text { Faiqatu } \\
1 \\
\text { Hikma } \\
\text { h dan J. } \\
\text { Faradin } \\
\text { ata } \\
\text { Ananti } \\
\text { o }\end{array}$ & 2016 & $\begin{array}{l}\text { Jurnal } \\
\text { Teknolo } \\
\text { gi } \\
\text { Informas } \\
\text { i dan } \\
\text { Terapan, } \\
\text { Vol. 02, } \\
\text { No. 02, } \\
\text { Januari } \\
2016 \\
\text { dengan } \\
\text { ISSN: } \\
\text { 2354- } \\
838 X\end{array}$ & $\begin{array}{l}\text { Perancang } \\
\text { an dan } \\
\text { Pembuata } \\
\text { n Aplikasi } \\
\text { Sensus } \\
\text { Harian } \\
\text { Rawat } \\
\text { Inap } \\
\text { Dengan } \\
\text { Pemrogra } \\
\text { man } \\
\text { Berbasis } \\
\text { Web di } \\
\text { Rumah } \\
\text { Sakit } \\
\text { Umum } \\
\text { Kaliwates } \\
\text { Jember }\end{array}$ & 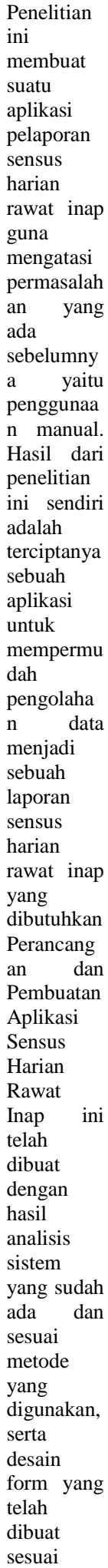 \\
\hline
\end{tabular}

Johni S Pasaribu, Johnson Sihombing 


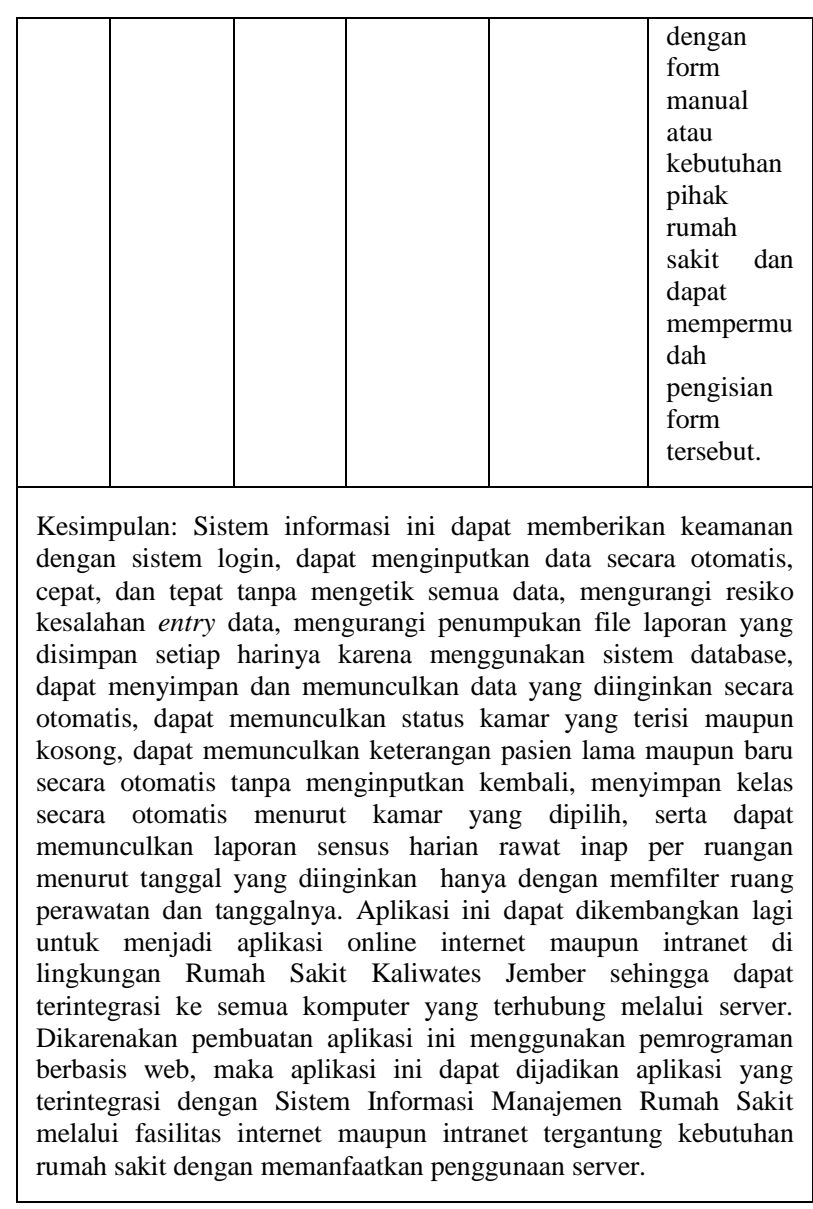

\section{Analisis dan Perancangan}

Penelitian ini menggunakan metode RUP yaitu proses-proses: pemodelan bisnis, pengumpulan kebutuhan, analisis dan desain, implementasi dan pengujian.

\section{III.1 Pemodelan Bisnis}

Pada tahap ini, penulis melakukan komunikasi langsung dengan pihak Klinik Sehat Margasari Bandung. Komunikasi yang dilakukan berupa wawancara dengan Direktur, Manager, Dokter Pelaksana, Administrasi, Keuangan dan Farmasi. Adapun hasil dari wawancara ini adalah proses bisnis dari rumah sakit yang dapat dilihat pada Gambar II berupa diagram aktivitas.

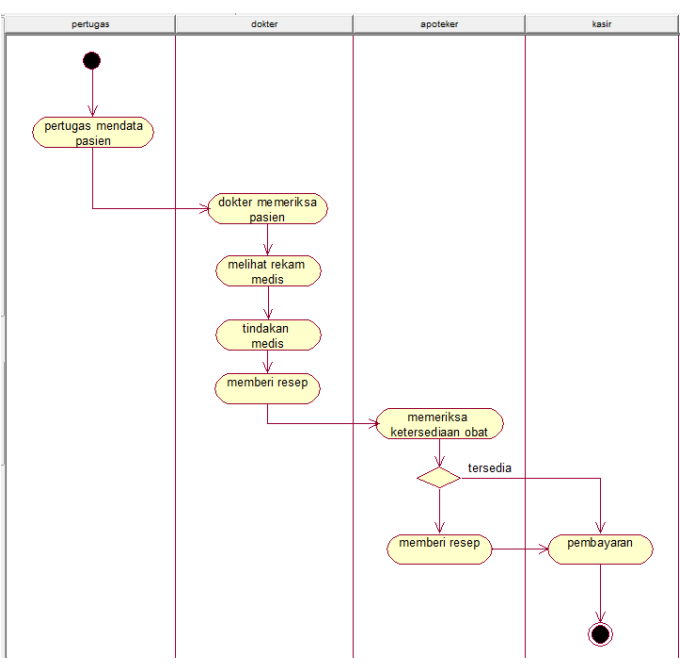

Gambar II. Proses Bisnis atau Diagram Aktivitas

\section{III.2 Pengumpulan Kebutuhan}

Adapun kebutuhan fungsional dan kebutuhan non-fungsional perangkat lunak ini adalah sebagai berikut:

Tabel 2. Kebutuhan Fungsional

\begin{tabular}{|c|c|c|}
\hline No & $\begin{array}{l}\text { Kebutuhan } \\
\text { Fungsional }\end{array}$ & Yang dilakukan aktor \\
\hline 1 & $\begin{array}{lr}\text { Sistem } & \text { harus } \\
\text { melakukan } & \text { login } \\
\text { terlebih } & \text { dahulu } \\
\text { sebelum } & \text { dapat } \\
\text { diakses } & \end{array}$ & $\begin{array}{l}\text { Petugas, dokter, apoteker, kepala } \\
\text { puskesmas, administrasi } \\
\text { melakukan login terlebih dahulu }\end{array}$ \\
\hline 2 & $\begin{array}{l}\text { Sistem harus mampu } \\
\text { menerima } \\
\text { pendaftaran pasien } \\
\text { baru }\end{array}$ & $\begin{array}{l}\text { Petugas melakukan pendaftaran } \\
\text { pasien baru }\end{array}$ \\
\hline 3 & $\begin{array}{lr}\text { Sistem harus } & \text { mampu } \\
\text { melakukan rekam } \\
\text { medis pasien }\end{array}$ & $\begin{array}{l}\text { Dokter melakukan rekam medis } \\
\text { pasien. }\end{array}$ \\
\hline 4 & $\begin{array}{l}\text { Sistem harus mampu } \\
\text { menyimpan data } \\
\text { tindakan medis yang } \\
\text { telah dilakukan }\end{array}$ & $\begin{array}{l}\text { Dokter melakukan tindakan medis } \\
\text { dan disimpan dalam sistem }\end{array}$ \\
\hline 5 & $\begin{array}{l}\text { Sistem harus mampu } \\
\text { mengelola data obat }\end{array}$ & $\begin{array}{l}\text { Apoteker menginput obat yang } \\
\text { masuk maupun yang keluar }\end{array}$ \\
\hline 6 & $\begin{array}{l}\text { Sistem harus mampu } \\
\text { mengeluarkan } \\
\text { laporan klinik }\end{array}$ & \begin{tabular}{lll} 
Kepala & Klinik & \multicolumn{2}{c}{ melakukan } \\
pencarian laporan & klinik per \\
periode yang diberikan & &
\end{tabular} \\
\hline
\end{tabular}


7

Sistem harus mampu Admin memasukkan transaksi mengelola

pembayaran pembayaran tindakan medis maupun obat ke dalam sistem

\begin{tabular}{|c|c|c|}
\hline No & $\begin{array}{l}\text { Kebutuhan } \\
\text { Non- } \\
\text { Fungsional }\end{array}$ & Uraian \\
\hline 1 & Operasional & $\begin{array}{l}\text { Sistem Operasi: Windows } 7 / 32 \\
\text { bit; Spesifikasi Komputer: } \\
\text { Processor (Pentium } 4 \text { / Dualcore } \\
1,6 \text { Ghz), RAM: } 512 \text { MB, VGA: } \\
256 \text { MB, Monitor: 14' inch, } \\
\text { Keyboard: Type USB Cable } \\
\text { Standar 101/102 key, Mouse: } \\
\text { Type USB Cable with optical; } \\
\text { Web Browser: Google Chrome, } \\
\text { Internet Explorer \& Mozilla } \\
\text { Firefox; Web Server: Apache; } \\
\text { Database Server: MySQL; Yii } \\
\text { Framework versi 1.1; Sublime } \\
\text { Teks 3; XAMPP versi 1.7.3 } \\
\text { dengan support PhpMySQL. }\end{array}$ \\
\hline 2 & Keamanan & $\begin{array}{l}\text { Sistem aplikasi dan database } \\
\text { dilengkapi dengan password; } \\
\text { dilengkapi dengan CCTV di ruang } \\
\text { baca dan ruang penyimpanan tas }\end{array}$ \\
\hline 3 & Informasi & $\begin{array}{l}\text { Digunakan untuk menampilkan } \\
\text { tata cara pendaftaran pasien baru; } \\
\text { digunakan untuk menampilkan } \\
\text { informasi bila user salah } \\
\text { memasukkan } \\
\text { memberikan laporan identitas } \\
\text { pasien sudah lengkap }\end{array}$ \\
\hline
\end{tabular}

\section{III.3 Analisis dan Desain}

Penulis menggunakan usecase diagram untuk mendefinisikan aktivitas-aktivitas pengguna sistem dan interaksi antara pengguna dengan sistem maupun interaksi antar pengguna. Diagram use case digunakan untuk mengetahui fungsi-fungsi apa saja yang ada dalam sebuah sistem dan siapa saja yang berhak menggunakan fungsi-fungsi tersebut. Berikut ini berisikan use case diagram untuk sistem informasi rekam medis pasien rawat jalan berbasis web di Klinik Sehat Margasari.

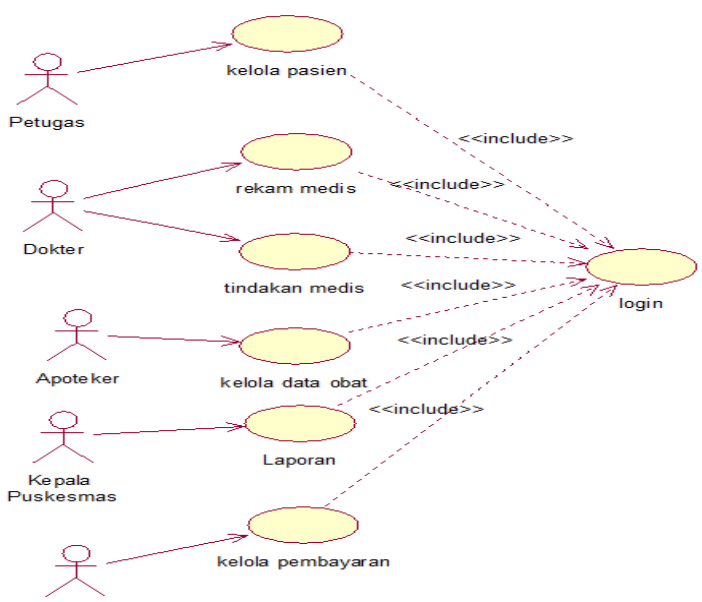

Gambar III. Use Case Diagram

Bagian ini menjelaskan transformasi model data yang dihasilkan oleh proses analisis menjadi struktur data yang dibutuhkan pada saat implementasi.

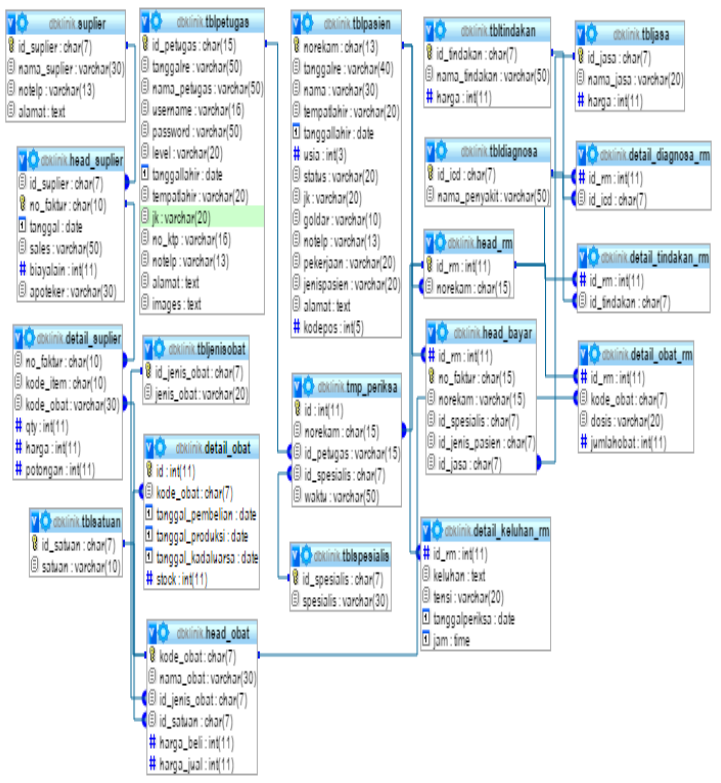

Gambar IV. Rancangan Desain Basis Data

\section{III.4 Implementasi Antar Muka}

Setelah melakukan semua tahapan tadi sesuai dengan metodologi RUP, pada tahap implementasi ini akan dijelaskan beberapa hasil dari penelitian sistem informasi pasien rawat jalan berbasis web di Klinik Sehat Margasari Bandung. Gambar V Dialog Screen Login berfungsi agar petugas/dokter/apoteker/admin dapat mendaftarkan diri. Adapun uraiannya: buka 
aplikasi Sistem Informasi Rekam Medis Pasien Rawat Jalan Klinik Sehat Margasari, pilih menu Login, isi semua field yang sudah disediakan.

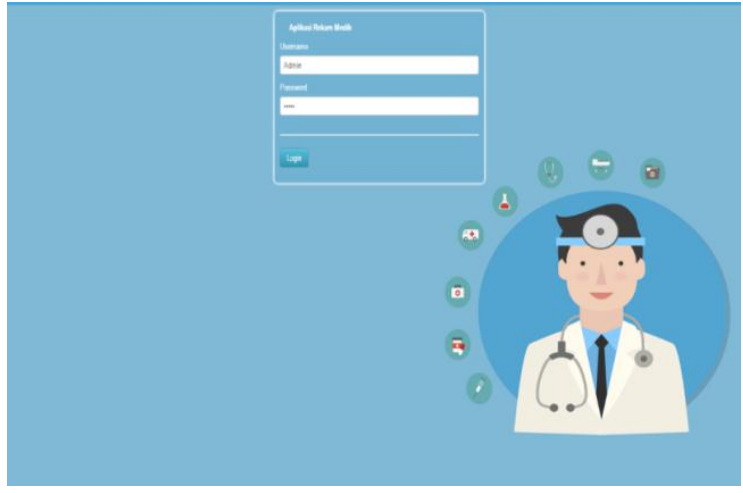

Gambar V. Dialog Screen Login

Gambar VI Tampilan awal setelah login yang merupakan bagian website setelah login. Pada dialog screen ini tersedia menu-menu Pasien, Petugas, Lain-lain, Obat, Pembelian Obat, Antrian Poli, Data Obat, Pembayaran, Laporan.

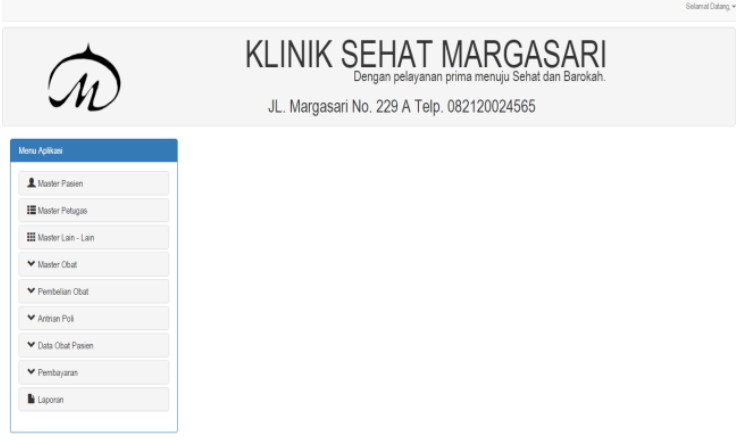

Gambar VI. Form Tampilan Awal

Pada menu Master Pasien ada sub menu Tambah Pasien dan Lihat Pasien. Pada menu Tambah Pasien, dimasukkan semua data dengan benar, apabila ada kesalahan maka sistem akan memunculkan pesan error. Berikut ini ditunjukkan Form Input Pasien:

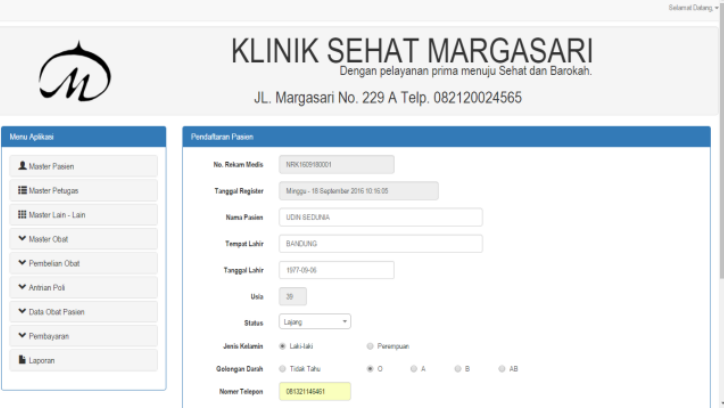

\section{Gambar VII. Form Input Pasien}

Menu Master Petugas tidak jauh berbeda dengan Menu Master Pasien. Pada menu Master Petugas ada sub menu Tambah Petugas dan Lihat Petugas. Pada menu Tambah Petugas, dimasukkan semua data dengan benar, dan apabila ada kesalahan maka sistem akan memunculkan pesan error. Bila semua field yang ada telah diisi, maka jika sudah klik Kirim dan akan di direct ke link Tampil Data Petugas seperti gambar VIII.

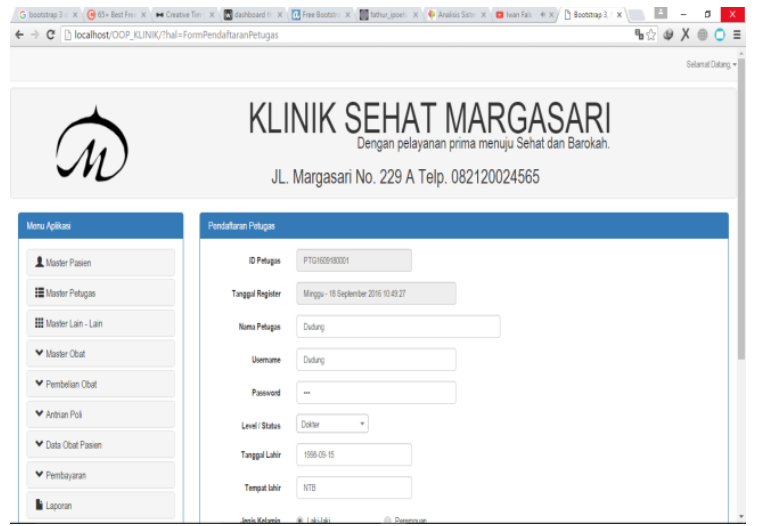

Gambar VIII. Form Input Petugas

Selanjutnya pada menu Master Lain - Lain berisi sub menu Master Jasa, Master Satuan, Master Tindakan, Master Diagnosa, Master Jenis Obat, Master Spesialis, dan Master Supplier. Master Jasa berisikan jasa dari tarif yang dikenakan untuk sekali pemeriksaan dokter, seperti pada gambar IX. Seperti pada menu Master Lain - Lain, semua data yang dimasukkan langsung muncul pada bagian bawah Form. Pada menu ini ada 2 menu yaitu Hapus dan Edit data yang telah dimasukkan. 


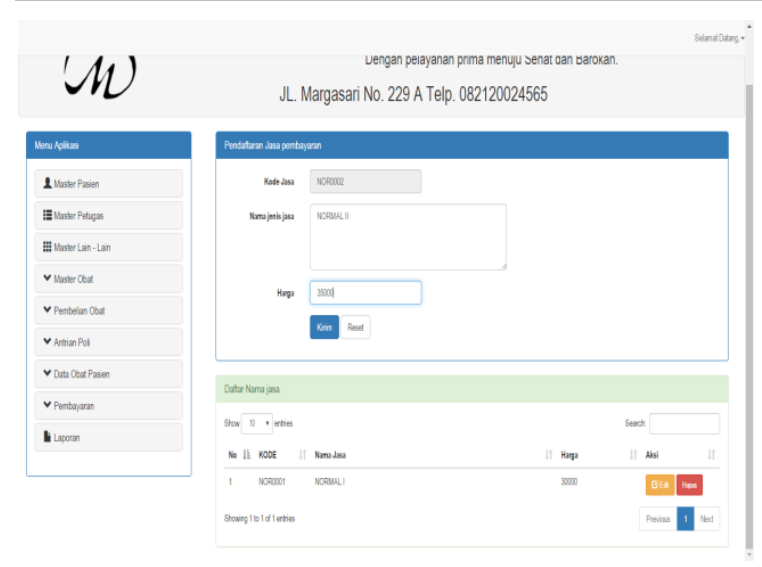

Gambar IX. Form Jasa Pembayaran

Setelah itu ada menu Master Obat, yang berisi input obat dan tambah stock obat. Pertama input obat yang digunakan untuk memasukan data obat mulai dari nama tanggal kadaluarsa sampai stock seperti gambar X.

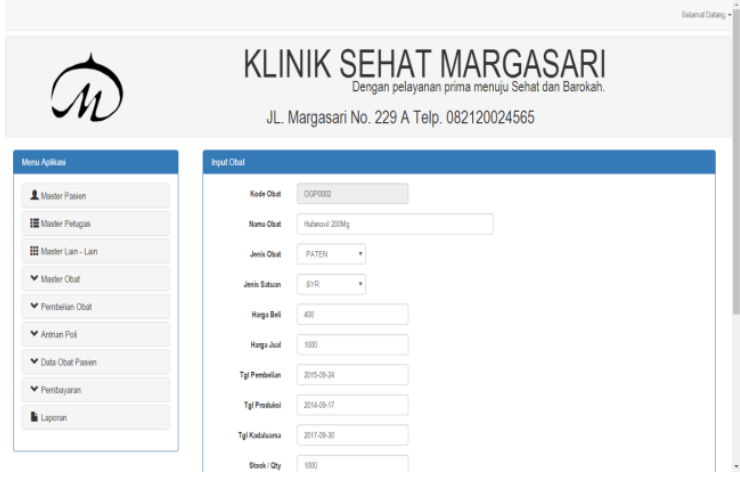

\section{Gambar X. Form Input Obat}

Setelah data diinputkan maka pada form yang sama akan ada tampilan dimana semua obat yang telah diinputkan ditampilkan seperti pada gambar XI. Pada form tersebut ada menu Edit dan Hapus, semua menu yang seperti sama seperti menu edit dan hapus sebelumnya.

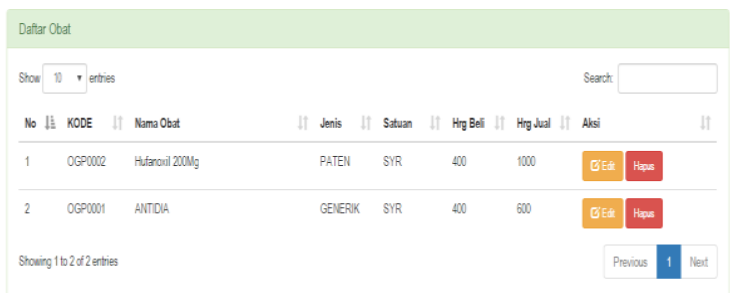

Tombol detail rekam medis untuk melihat keseluruhan data dari pasien bersangkutan seperti gambar XII.
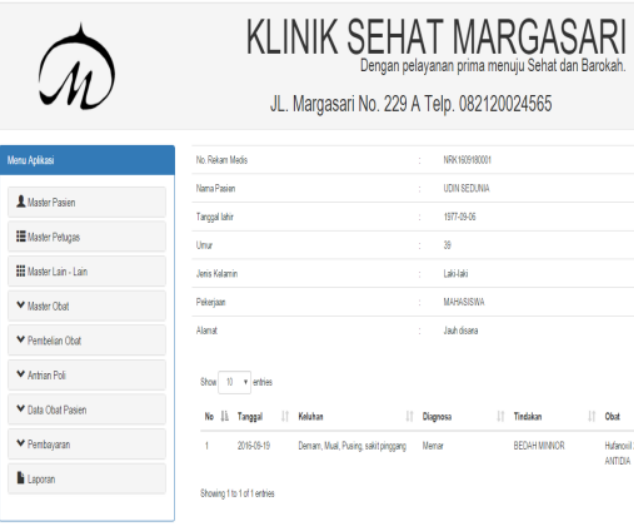

JL. Margasari NNo. 229 A Telp. 082120024565

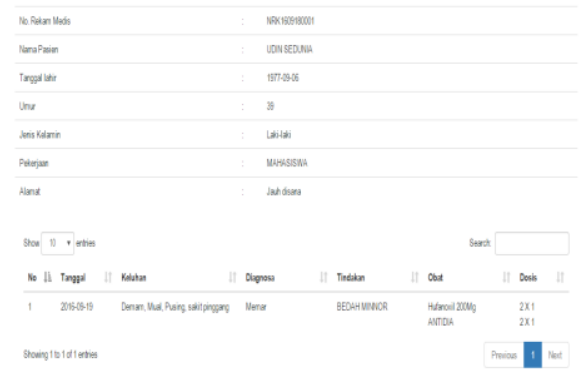

Gambar XII. Form Detail Rekam Medis Pasien

\section{III.5 Hasil Pengujian}

Dalam Pengujian ini dilakukan dengan metode Black Box testing, yaitu pengujian yang mengabaikan mekanisme internal sistem atau komponen dan fokus semata-mata pada output yang dihasilkan yang merespon input yang dipilih dan kondisi eksekusi (Hetzel, 1998). Pengujian yang dilakukan disini untuk mengevaluasi pemenuhan sistem atau komponen dengan kebutuhan fungsional tertentu (Romeo, 2003). Di bawah ini beberapa fungsionalitas pengujian tiap modul beserta dengan hasil rekapitulasi saran dari User atau penguji.

Tabel 4. Hasil Pengujian

\begin{tabular}{cllll}
\hline \hline No & $\begin{array}{l}\text { Fungsi } \\
\text { Yang } \\
\text { Diuji }\end{array}$ & $\begin{array}{l}\text { Cara } \\
\text { Pengujian }\end{array}$ & $\begin{array}{l}\text { Hasil } \\
\text { Yang } \\
\text { Diharapk } \\
\text { an }\end{array}$ & $\begin{array}{l}\text { Hasil } \\
\text { Pengujian }\end{array}$ \\
\hline \hline 1 & $\begin{array}{l}\text { Pengujian } \\
\text { login } \\
\text { admin }\end{array}$ & $\begin{array}{l}\text { Masukan } \\
\text { username dan } \\
\text { password }\end{array}$ & $\begin{array}{l}\text { Jika username } \\
\text { dan password } \\
\text { benar maka } \\
\text { login berhasil }\end{array}$ & $\begin{array}{l}\text { Berhasil } \\
\text { login admin }\end{array}$ \\
& & $\begin{array}{l}\text { Jika username } \\
\text { dan password } \\
\text { salah maka } \\
\text { login gagal }\end{array}$ & Gagal login \\
& $\begin{array}{l}\text { Pengujian } \\
\text { login } \\
\text { admin }\end{array}$ & $\begin{array}{l}\text { Masukan } \\
\text { username dassword }\end{array}$ & \\
& & &
\end{tabular}

Gambar XI. Form Daftar Obat 


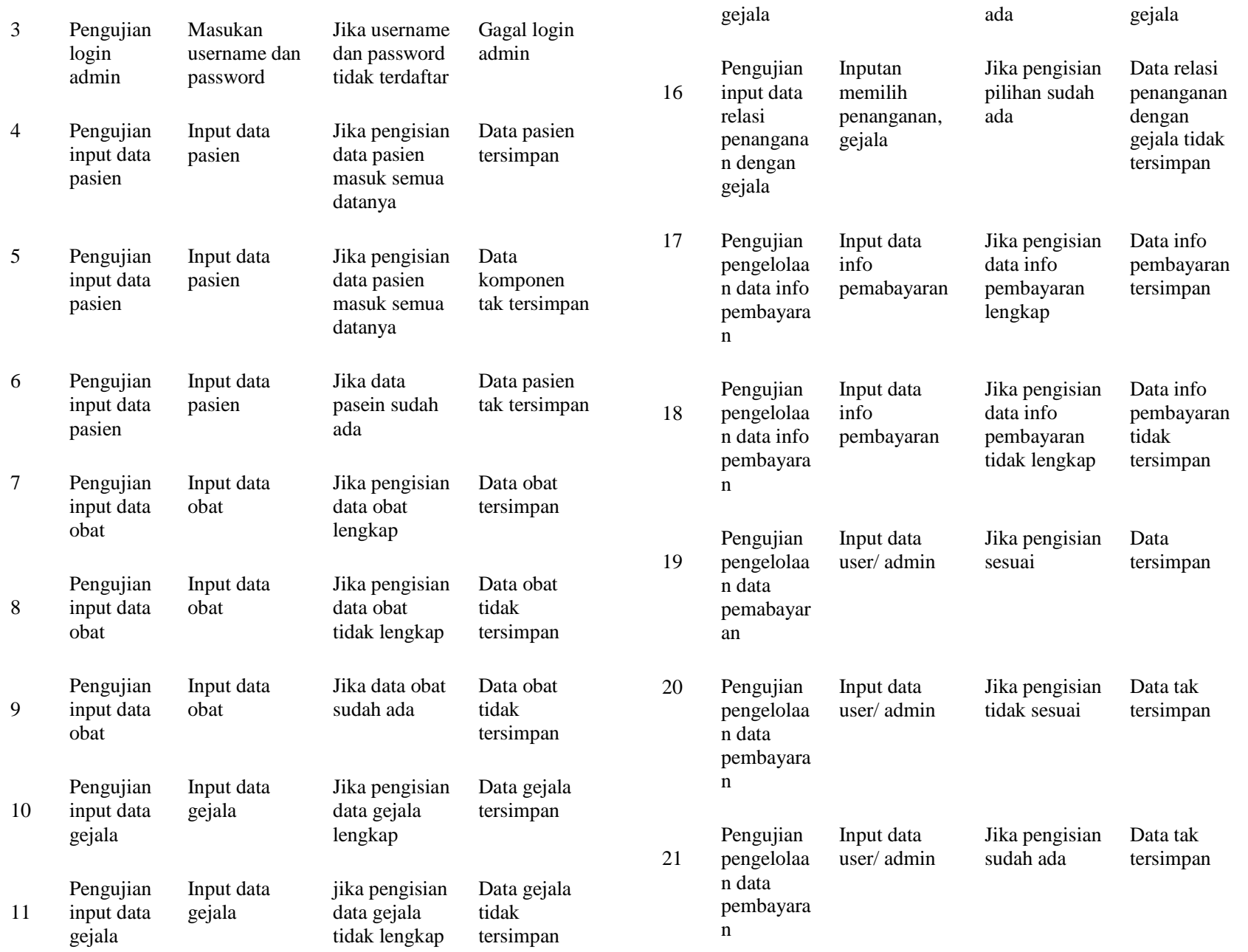

Pengujian Input data Jika data Data gejala input data gejala gejala sudah tidak

gejala

Pengujian

13 input data

penangana

n dengan

gejala

Pengujian

Inputan

14 input data

relasi

komponen

dengan

gejala

Pengujian

15 input data

relasi

penangan

dengan pilihan tidak komponen lengkap

gejala

$$
\begin{aligned}
& \text { Inputan } \\
& \text { memilih } \\
& \text { penangan, }
\end{aligned}
$$
gejala dengan tersimpan

Jika data penanganan/g membuat ejala/kerusaka data relasi ada tersimpan

Jika pengisian Data relasi pilihan peanganan lengkap

dengan gejala tersimpan gejala tidak Tidak dapat $\mathrm{n}$ yang akan penangana $\mathrm{n}$ dipilih tidak dengan

\section{KESIMPULAN DAN SARAN}

Berdasarkan laporan yang telah dibahas sebelumnya, kesimpulan dari topik Perancangan Sistem Informasi Pasien Rawat Jalan Dengan Framework YII di Klinik Sehat Margasari Bandung yaitu sebagai berikut:

1. Aplikasi perancangan sistem informasi pasien rawat jalan ini merupakan sebuah aplikasi yang bermanfaat dalam media informasi sebagai bentuk perkembangan teknologi dan informasi.

2. Perancangan sistem informasi pasien rawat jalan ini bisa mempermudah petugas dalam menangani dan mengelola data pasien rawat jalan.

3. Menghasilkan sistem yang dapat mempermudah dalam mengolola data dokter, pasien, obat, stok 
obat, transaksi dan mencetak kartu pasien yang berfungsi mempermudah administrasi pendaftaran pasien saat kembali berkunjung dengan menggunakan sistem pada komputer.

4. Perancangan sistem informasi pasien rawat jalan pada klinik yang diajukan ini memberi suatu alternatif pemecahan masalah dalam sistem registrasi dan pengambilan nomor untuk pasien.

Adapun saran-saran yang dapat digunakan untuk pengembangan perangkat lunak yang sudah dibuat sebagai berikut:

1. Menambahkan fitur pembayaran via debit.

2. Menambahkan fitur rawat inap.

\section{REFERENSI}

Azwar, A. (1996). Pengantar Administrasi Kesehatan. Edisi ketiga, Jakarta: Binarupa Aksara

Basiroh dan Burhanuddin, A. (2016). Sistem Informasi Pengelolaan Data Pasien Rawat Jalan Pada Klinik Akupuntur Dan Home Care Sehat Migoaeni. Seminar Nasional Teknologi Informasi dan Multimedia 2016 di STMIK AMIKOM Yogyakarta, 6-7 Februari 2016, ISSN: 2302-3805.

Budi, S. C. 2013. Bahan Ajar Desain Formulir Rekam Medis. Yogyakarta: Sekolah Vokasi Diploma Rekam Medis UGM.

Dewanto, W. K., Hikmah, F., dan Anantio, J.F. (2016). Perancangan Dan Pembuatan Aplikasi Sensus Harian Rawat Inap Dengan Pemrograman Berbasis Web Di Rumah Sakit Umum Kaliwates Jember. Jurnal Teknologi Informasi dan Terapan, Vol. 02, No. 02, Januari 2016, ISSN: 2354-838X.

Direktorat Jendral Pelayanan Medik. (1997). Pedoman Penyelenggaraan Rekam Medik Rumah Sakit di Indonesia. Jakarta: Departemen Kesehatan RI.

Hetzel, B. (1998). The Complete Guide to Software Testing Second Edition. New York: John Wiley \& Sons.
Loudon. (2007). Sistem Informasi Manajemen Mengelola Perusahaan Digital. Jakarta : Pearson Education.

Peraturan Menteri Kesehatan Nomor: 749a/MenKes/Per/XII/1989. Tentang Rekam Medik. Jakarta: DepKes RI.

Romeo. (2003). Testing dan Implementasi Sistem. Surabaya: STIKOM Surabaya.

Topan, M., Wowor, H.F., dan Najoan, X.B.N. (2015). Perancangan Sistem Informasi Manajemen Rumah Sakit Berbasis Web Studi Kasus: Rumah Sakit TNI AU Lanud Sam Ratulangi. E-journal Teknik Informatika, volume 6, No. 1 (2015), ISSN : 2301-8364.

Widiarta. (2007). Komputerisasi Sensus Harian Rawat Jalan di Rumah Sakit Pembinaan Kesejahteraan Umat Muhammadiyah Karanganyar. Amd.Perkes. KTI, APIKES. 